\title{
Understanding plagiarism in Indonesia from the lens of plagiarism policy: lessons for universities
}

\author{
Akbar Akbar ${ }^{1,2^{*}}$ (D) and Michelle Picard ${ }^{2,3}$
}

\author{
* Correspondence: akbar@uon.edu. \\ au; akbarakbar@iainpalopo.ac.id \\ ${ }^{1}$ Institut Agama Islam Negeri \\ Palopo, Palopo, Sulawesi Selatan, \\ Indonesia \\ ${ }^{2}$ The University of Newcastle \\ Newcastle, Australia \\ Full list of author information is \\ available at the end of the article
}

\begin{abstract}
Plagiarism is viewed as a critical issue that can hinder the development of creativity and innovation in Indonesia. Thus, since the early 2000s the Indonesian government has endeavoured to develop policies to address this issue. In response to national policy, Indonesian educational institutions have made serious institutional efforts to address the plagiarism issue. Research in the Indonesian Higher education context on plagiarism has focussed on reporting prevention and mitigation efforts. However, little has been discussed about the communication of these efforts in policy across the different institutional levels of Indonesian Higher Education. This study aims at exploring the anti-plagiarism efforts by determining the main features (or discourses) reflected in plagiarism policy in Indonesian HE from national to institutional level. Two web-based resources namely the official website of The General Directorate of Research, Technology and Higher Education (retrieved 2015), and the website of Bandung Institute of Technology (retrieved 2015) were used to ascertain the most appropriate policies to include in the study. Critical Discourse Analysis (CDA) was used to reach explanatory understanding of how the policies (discursive events) demonstrate through their linguistic repetitions and other forms intertextuality, their relative positions within the Indonesian Higher Education institutional hierarchy and consequently provide some insight into the social practices and understandings of plagiarism underlying the creation of the documents. This study revealed that perhaps because of the rigid boundaries and hierarchies represented between the documents, the university policy does not show much transformation from the documents at a Ministry level, hence the definition of plagiarism remains broad and the levels of plagiarism and sanctions for plagiarism remain undefined. This can potentially lead to inconsistencies in developing effective practices preventing plagiarism.
\end{abstract}

Keywords: Plagiarism policy, Indonesian higher education, Critical discourse analysis

\section{Introduction}

Plagiarism is viewed as a fundamental issue that can hinder the development of creativity and innovation in Indonesia (Wibowo 2012). Thus, since the early 2000s the Indonesian government has endeavoured to develop policies to address this issue. In 2003, the Indonesian government established the Act of the Republic of Indonesia Number 20 Year 2003 on the National Education System (ANES 2003). This Act regulates the education system in Indonesia as its general purpose and includes plagiarism regulations and penalties to deter plagiarism.

(c) The Author(s). 2019 Open Access This article is distributed under the terms of the Creative Commons Attribution 4.0 International License (http://creativecommons.org/licenses/by/4.0/), which permits unrestricted use, distribution, and reproduction in any medium, provided you give appropriate credit to the original author(s) and the source, provide a link to the Creative Commons license, and indicate if changes were made. 
Seven years later, a high-profile case of an Indonesian academic accused of plagiarism by an international journal hit the headlines in Indonesia and worldwide (The Jakarta Post 2010). Within months, a specific HE regulation was formulated, the timing of this activity suggesting a direct response to this event. The development of this regulation also suggests that the Indonesian government views HE institutions as the centre of research and technology for Indonesia and considers it important to prevent academic misconduct including plagiarism in such institutions. Consequently, the Ministry of National Education of the Republic of Indonesia Regulation, Number 17, 2010 on Prevention and Mitigation of Plagiarism in Higher Education (RPMPHE 2010) was established to provide clearer concepts and contexts of plagiarism including guidance on preventive and curative actions in response to plagiarism incidences by HE institution students and staff.

In response to this and subsequent national policy, Indonesian educational institutions have made efforts to address the plagiarism issue through prevention and mitigation (as reported in Adiningrum 2015; Adiningrum et al. 2013; Siaputra 2013, Siaputra and Santosa 2015). Strategies introduced include workshops and dissemination of plagiarism information, statements on webpages, mandatory uploading of academic work to a database for Indonesian academic staff and students called Garba Rujukan Digital (Garuda) (Dikti 2011a) and validation of academic work through peer review by a specialised team in each institution before promotion of academic staff (Dikti 2011b). However, among the research, little attention has been paid to the relationship between plagiarism policy and plagiarism prevention practices and, furthermore, how the various policy documents are interconnected and affect each other as well as social practices. These explorations are important to explore the best mechanisms to enhance Indonesian Higher education efforts to curb plagiarism.

\section{Methodology}

This study aims to determine the main discourses reflected in plagiarism policy in Indonesian HE from national to institutional level using Critical Discourse Analysis (CDA). To achieve this aim, two resources were used to ascertain the most appropriate policies to include in the study relevant sites. Firstly, the official website of the General Directorate of Research, Technology and Higher Education of Indonesia was used to find relevant documents. The use of this website was expected to provide necessary government or university documents developed in relation to plagiarism. Furthermore, the website of Bandung Technology Institute was used to search for plagiarism policy at a university level. ITB was selected for two reasons. The first reason was that the plagiarism incident possibly triggering the specific HE plagiarism policy at a ministry level as previously stated, occurred at this university. Another reason is that the university is a nationally high ranked university which is frequently positioned as an exemplar to other universities who could potentially learn from and emulate the university's plagiarism policy. Four sets of key plagiarism policy documents level were identified and collected before being analysed since they were developed by socially influential agents at ministerial and institutional levels who have both the authority to devise and enact plagiarism policy. The collected documents were first analysed for their positions within the top-down Indonesian Higher Education institutional hierarchy. Then, social agents who enacted and are impacted by the policy documents were identified. Then, 
intertextuality among documents was analysed in detail before presenting the discursive features of the policy documents. As noted by Fairclough, certain "orders of discourse are associated with educational organisations", and especially policy documents. There are specific expectations around style, and level of formality, hence genre, activity type, and style are less emphasised as a focus for CDA in this paper since they are similar across the documents. Instead, intertextuality is explored in more detail. The focus was on what Fairclough calls the "vertical dimensions of intertextuality" (Fairclough, 1992: 271) where direct quotations from previous texts, repetitions of linguistic items, "discourses" ("traditionally ... discussed in terms of 'content', 'ideational meanings', 'topic' and 'subject matter"' (Fairclough, 1992: 286). This is also because the educational environment in Indonesia is extremely hierarchical with decisions generally being made at a ministerial level and then moving down to the institutional level.

\section{Findings and discussions}

\section{Hierarchy of selected documents}

Policy documents referring to plagiarism presented in this section are Acts, Regulations, Circular Letters and Ethical or Honour Codes. These textual artefacts represented differing levels of authority, namely presidential, ministerial, organisational and institutional levels. They also have a descending hierarchy in order of their perceived authority within the Indonesian Higher Education system. The first document is The Act of the Republic of Indonesia Number 20, 2003 on National Education System (ANES 2003), which was enacted by the President of the Republic of Indonesia (PRI) in July 2003. According to the Basic Constitution of the Republic of Indonesia article 4, "The President of the Republic of Indonesia wields power of government according to the constitution". The PRI, as the main actor in the establishment of the ANES 2003, had a significant role in governance to regulate and determine the national education direction. The ANES 2003 is a vital policy document because of its role amongst plagiarism policy documents as a general guideline for national education by providing a broad description for national education implementation. As noted in the document itself, "Acts are written law that contain a binding legal norms in general and established or designated by the institution of the state or the competent authority through procedures specified in the legislation" (Presiden Republik Indonesia 2011, p. 2).

The ANES 2003 document also holds a powerful position in terms of practice since it determines the authority to impose sanctions on plagiarists. Thus, the ANES 2003 was hierarchically positioned after the Basic Constitution of The Republic of Indonesia 1945 and House of Representative Decree (see, Presiden Republik Indonesia 2011, p. 4). Of the analysed documents, the ANES 2003 played an important role as the "key speaker" of plagiarism policy documents from its release date. In other words, this document had the highest power as it "speaks" earlier than other documents and had effects on planning, preparation and implementation of national education from the central government to local government, formal and non-formal education institutions and levels of national education, including primary, secondary and tertiary education. This is also reflected as is shown later in the "vertical intertextuality" (Fairclough, 1992: 271) revealed between this document and the subsequent documents. 
The second document selected was the RPMPHE 2010, which was enacted by the Minister of National Education of the Republic of Indonesia (MNERI) in August 2010, 7 years after the ANES 2003. This document was regarded as the most important policy document after the ANES 2003 because the MNERI is second only in importance in Indonesia to the PRI and was assigned to be responsible for management of the educational sector by the central government (see Presiden Republik Indonesia 2015). The RPMPHE 2010 narrowed the general statements of the ANES 2003 to more specific goals. The former set the focus of educational goals on HE context. The document had applicable power and significant effects on the practices of preventing and mitigating plagiarism in higher education throughout Indonesia, from universities in the capital to colleges in remote and underdeveloped areas, from state universities to private universities and to different types of HE providers, such as academies, polytechnics and colleges (see chapter I article 1 verse 8 of RPMPHE 2010).

The third set of documents examined were two circular letters from the General Directorate of Higher Education of the Republic of Indonesia and one circular letter from the Director of Research and Community Service (DRCS). On 10 October 2010, the General Directorate released the first circular letter on the prevention and mitigation of plagiarism to address perceived emerging misunderstanding amongst academics about content of the RPMPHE 2010 (article 8, unit 3) on peer review for promotion of professors. Additionally, on February 2011 another circular letter was released to describe the need for validation of academic works for promotion of head lectors/professors candidature, which narrowed the RPMPHE 2010 to the topic of professor promotion in HE contexts. The third circular letter was an instruction to journal managers and periodicals in Indonesian HE for publishing academic work. Through this letter, DRCS instructed journal managers and periodicals to upload online academic work via a specific database, the Garuda Portal. This circular letter was dated July 2011, almost a year after legalisation of the RPMPHE 2010. These two documents explicitly respond to the first two texts by directly addressing the content of the first two documents as well as responding to a perceived confusion/misunderstanding of the first two documents as identified through behaviours of the named actors: academics applying for promotion and their managers and journal managers and periodicals.

The fourth document analysed was the Decree of the Rector of the Bandung Institute of Technology on Guideline of Ethic Codes for Research Integrity (DGECRI of ITB) established on 18 March 2011 as prepared by the rector of ITB. This document is institutional in scope and concerns the institutional education system, including learning, teaching and research. The policy had important implication for ITB students and academic staff, such as faculty, schools and study programs and, as noted in the document itself, all agents including researchers, lecturers, academic staff and students of ITB must comply with the decree in this document.

Figure 1. below shows the relationship between policy documents as discussed. They are arranged in a hierarchical position from national plagiarism policy at the top to the institutional policy at the lowest level. This hierarchy informs the context and focus of each document. In addition, the documents all include what Fairclough terms "manifest intertextuality" (Fairclough, 1992: 271) in that they explicitly quote each other, in many cases incorporate "an individual other text without the latter being explicitly cued" and/or have repeated lexical items or content as is explored in more detail in the latter 


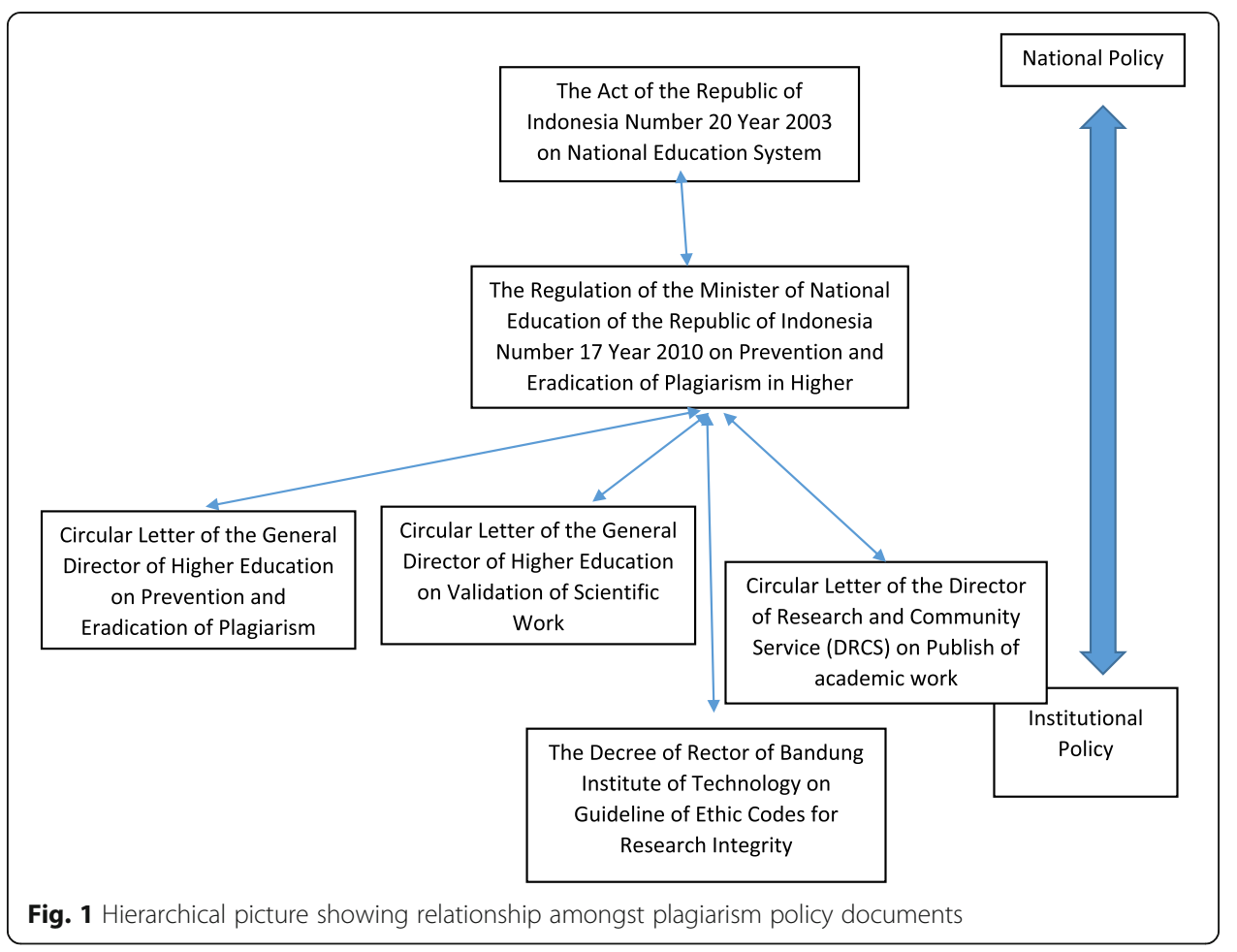

sections of this paper. The lower level policy documents all quote the higher-level documents in their preambles and/or opening statements showing that higher-level documents both carry authority in themselves and support the authority of the lower level documents.

\section{Social agents in the plagiarism policy documents}

ANES 2003 includes policy related to plagiarism in articles 25 and 70 and the most frequent agents referred to were "graduates" who were mentioned twice and paired together with the phrases "whose academic work" and "university". This lexical use set the context of higher education and constructed the notion of what could potentially be plagiarised work. To obtain "degrees" was the main context within which avoiding plagiarism was referred to in this document. Thus, the social agents addressed in this document were limited to those who had obtained an academic degree and not those who were studying to obtain a degree.

On the other hand, RPMPHE 2010 addressed agents who might commit plagiarism undertaking degrees and completing degrees and social agents involved in the prevention and mitigation of plagiarism. In this policy document, plagiarists were mentioned eight times in this document and plagiarism was addressed in the beginning of the document. "Student(s)/lecturer(s)/researcher(s)/staff" were all referred to as potential committers of plagiarism. However, when comparison was made between students and lecturers. The use of word "lecturer(s)" (36 times) was higher than students (28 times) because lecturers were involved both as plagiarists and "in the policing of plagiarism" (see chapter V, article 10, unit 2). However, a higher proportion of texts focused on the regulation of plagiarism amongst lecturers/researchers/staff (see article 11) indicating 
that this document emphasised plagiarism amongst lecturers more so than students. Lecturers were frequently paired together as "lecturer(s)/researcher(s)/staff" and were mentioned more (28 times) with this phrase. In addition, a number of synonyms for lecturers were used, such as assistant professors, associate professors and professors endeavouring to include academic staff in all levels. The RPMPHE 2010 further provided a higher proportion of units for faculty plagiarism than students regulating the handling and sanctions for plagiarism (see chapter V). The higher proportion of regulating faculty plagiarism than student plagiarism implies that this policy emphasised addressing faculty plagiarism more so than student plagiarism. Perhaps this is because of the strong emphasis on plagiarism among lecturers in the media coverage immediately preceding the development of this policy (e.g. The Jakarta Post, 2010) and the greater potential public embarrassment if staff were to plagiarise. Thus we can see an element of what Fairclough calls "transformations" (Fairclough, 1992: 287) refocussing the attention on academic staff in response to the social and historical context.

The Regulation of the Ministry of National Education of the Republic of Indonesia Number 17, 2010 on Prevention and Mitigation of Plagiarism in Higher Education (RPMPHE 2010) emphasised that leaders of HE institutions were the agents who needed to proactively act on plagiarism prevention and mitigation efforts as leaders of higher education institutions were mentioned 16 times. Synonyms used for leaders were mentioned including "officers" appointed by leaders, "rectors, chiefs of colleges, and directors of polytechnics". These leaders were responsible for the management of preventive and punitive practices regarding plagiarism (see article 1, units 3 and 4). The leaders manage prevention and punishment of plagiarism in collaboration with agents at a meso-level of the universities, such as lecturers and heads of department (mentioned four times in the documents), and with agents at a macro level, such as the "academic senate, ethics commission and the minister" (see articles 10, 11 and 12). This document although having strong "manifest intertextuality" (Fairclough, 1992: 271) with the first document, 'transforms' into a more practical emphasis on the prevention and punishment of plagiarism.

The two circular letters of the General Director of Higher Education (GDHE) and one circular letter from the Director of Research and Community Service (DRCS) highlighted faculty plagiarism as the central issue because there was no mention students as social agents in plagiarism. Instead, lecturers were the most frequently mentioned agents, mentioned nine times in the three documents. There were also a number of similar lexical items used in these documents such as "assistant professors, associate professors, and professors". The two documents also mentioned protagonist agents for prevention and mitigation of plagiarism, such as the "central assessment team, validation team, managers of accredited journals, rectors/chiefs/directors, GDHE, and the General Secretary of the Ministry of National Education". The inclusion of the social agents indicates that the documents addressed the issue of plagiarism amongst prominent figures, such as professors and further completes the 'transformation' to a complete emphasis on academic and related staff.

A transformation back to the broader "academic community of ITB" occurred in the Decree of Rector of Bandung Institute of Technology on Guideline of Ethic Codes for Research Integrity (DGECRI of ITB). The academic community of ITB were addressed from the beginning of the policy document (see part 'Considering', point a, b, c) and 
were included four times in the documents. Other words used to represent academic community of ITB were "members" and "all parties" (mentioned three and eight times, respectively). The word "members" was used to personalise faculty, researchers, and students to the document. The overuse of "all parties" (mentioned eight times) intended to include sense of unity to equalise the roles of students, faculty and researchers in implementing the ethic codes without discrimination. Indeed, this document addressed equally both students and faculty as social agents to maintain academic integrity (both mentioned nine times) although students were also included as victims of faculty plagiarism (point $7, \mathrm{~h}$ and i). Thus, it appears that the DGECRI of ITB highlighted plagiarism amongst faculty and students more than the two circulars and the RPMPHE 2010 that it directly refers to and returns to a focus on all agents as originally demonstrated in the ANES 2003. Perhaps because this is an institutional level policy and students are always key agents in any university policy. However, because of the 'research focus' of the document, students' are less often active agents in the policy and as noted below, less detail is provided on practical measures to prevent student plagiarism than staff plagiarism.

Table 1. below summarises the social agents among the plagiarism policy documents by emphasising the frequency of referrals to the various agents in the documents.

\section{Intertextuality and discourses amongst Indonesian plagiarism policies}

Besides the social agents already discussed above, the intertextuality of texts amongst plagiarism policies was evaluated in terms of the repeated discourses (or 'content'/'subject matter'/'topic'). The following 'topics' that occur at all levels of the hierarchy are discussed below: definitions of plagiarism, prevention of plagiarism and punishment of plagiarism.

\section{Defining plagiarism amongst the policy documents}

Table 2 illustrates the contents of definition of plagiarism among the plagiarism policy documents identified in the hierarchy. These definitions were presented in accordance to the hierarchical position of the documents.

Plagiarism policy documents from all four different levels of the educational authorities proposed definitions of plagiarism. Each authority defined plagiarism in different ways from general notion to more specific definitions. The following quotation at the national policy level, the ANES 2003 mentioned plagiarism in chapter VI article 25 unit 2. No a specific definition of plagiarism was provided in this policy document.

\section{"An academic, professional, or technical and vocational degree awarded shall be} revoked, if his/her thesis/dissertation is a plagiarism".

In the ANES 2003 policy document plagiarism was mentioned, but not clearly defined. This lack of clarity could trigger confusion amongst students, faculty and policy makers in understanding what constitutes plagiarism. Moreover, the term "plagiarism" in the ANES 2003 definition was copied from the Translation of the ANES 2003 which was relatively different from the original document. The original document of the ANES 2003 used the terms "jiplak" which is a synonym for plagiarism, but is somewhat different. The term "jiplak" means to cheat, duplicate and copy (Kamus Besar Bahasa Indonesia (n.d.) but 
Table 1 Social agents among the plagiarism policy documents

\begin{tabular}{|c|c|c|c|}
\hline Documents & Social Agents & Frequency & Descriptions \\
\hline ANES 2003 & graduates & 2 & $\begin{array}{l}\text { Limited to those who had obtained } \\
\text { academic degree but not those who } \\
\text { were studying for a degree }\end{array}$ \\
\hline \multirow[t]{9}{*}{ RPMPHE 2010} & \multirow[t]{2}{*}{ lecturers } & \multirow[t]{2}{*}{36} & $\begin{array}{l}\text { Used in phrase: "lecturers/researchers/ } \\
\text { staff" }\end{array}$ \\
\hline & & & $\begin{array}{l}\text { Synonyms with assistant professors, } \\
\text { associate professors and professors }\end{array}$ \\
\hline & students & 28 & - \\
\hline & leader(s) & 16 & $\begin{array}{l}\text { Used synonyms: "rectors, chiefs of } \\
\text { colleges and directors of polytechnics }\end{array}$ \\
\hline & \multirow[t]{3}{*}{ senate } & \multirow[t]{3}{*}{11} & $\begin{array}{l}\text { To assign ethic commission to } \\
\text { investigate plagiarism allegation }\end{array}$ \\
\hline & & & Expose the result of investigation \\
\hline & & & Propose sanctions \\
\hline & ethics commissions & 2 & To conduct investigation \\
\hline & minister & 7 & To revoke professorship \\
\hline \multirow{8}{*}{$\begin{array}{l}\text { Two Circular Letters of GDHE and } \\
\text { a circular letter of Director of } \\
\text { Research and Community Service }\end{array}$} & Student & None & - \\
\hline & Lecturers & 9 & $\begin{array}{l}\text { Used synonyms: assistant professors, } \\
\text { associate professors and professors }\end{array}$ \\
\hline & $\begin{array}{l}\text { Central assessment } \\
\text { team }\end{array}$ & 2 & $\begin{array}{l}\text { In charge of assessment of credit point } \\
\text { to upgrade from associate professors } \\
\text { to professors. }\end{array}$ \\
\hline & Peer Reviewers & 2 & $\begin{array}{l}\text { Two or more professors from the same } \\
\text { discipline of the assessed promoted } \\
\text { professor candidature before the } \\
\text { Central Assessment Team. }\end{array}$ \\
\hline & $\begin{array}{l}\text { General Director of } \\
\text { Higher Education }\end{array}$ & 2 & The Chair of Central assessment team \\
\hline & $\begin{array}{l}\text { General Secretary of } \\
\text { the Ministry of } \\
\text { Education and } \\
\text { Culture. }\end{array}$ & 1 & $\begin{array}{l}\text { To receive professorship promotion } \\
\text { proposal. }\end{array}$ \\
\hline & Validation team & 1 & $\begin{array}{l}\text { In charge of validating proposed } \\
\text { scholarly works required for } \\
\text { professorship promotion }\end{array}$ \\
\hline & $\begin{array}{l}\text { Managers of } \\
\text { accredited journals }\end{array}$ & 1 & $\begin{array}{l}\text { To publish their journals in Garuda } \\
\text { Portal }\end{array}$ \\
\hline \multirow[t]{3}{*}{ DGECRI of ITB } & $\begin{array}{l}\text { Academic } \\
\text { community of ITB }\end{array}$ & 4 & $\begin{array}{l}\text { To personalise faculty, researchers and } \\
\text { students }\end{array}$ \\
\hline & All parties & 8 & $\begin{array}{l}\text { To equalises the roles of faculty, } \\
\text { researchers and students }\end{array}$ \\
\hline & Students and faculty & 9 & $\begin{array}{l}\text { To indicate the absence of } \\
\text { discrimination between students and } \\
\text { faculty }\end{array}$ \\
\hline
\end{tabular}

Table 2 The contents of defining plagiarism amongst plagiarism policy documents

\begin{tabular}{|c|c|c|c|c|c|c|}
\hline \multirow[t]{2}{*}{ Theme } & \multirow{2}{*}{$\begin{array}{l}\text { ANES } \\
2003\end{array}$} & \multirow{2}{*}{$\begin{array}{l}\text { RPMPHE } \\
2010\end{array}$} & \multicolumn{3}{|l|}{ Circular Letters } & \multirow{2}{*}{$\begin{array}{l}\text { Guidance of Ethics } \\
\text { for Research Integrity }\end{array}$} \\
\hline & & & $\begin{array}{l}\text { GDHE: Plagiarism } \\
\text { prevention and } \\
\text { Mitigation }\end{array}$ & $\begin{array}{l}\text { GDHE: Scientific } \\
\text { Work Validation }\end{array}$ & $\begin{array}{l}\text { DRCS: Uploading } \\
\text { academic work }\end{array}$ & \\
\hline $\begin{array}{l}\text { Defining } \\
\text { Plagiarism }\end{array}$ & $\begin{array}{l}\text { Chapter VI } \\
\text { Article } 25 \\
\text { unit } 2\end{array}$ & $\begin{array}{l}\text { Chapter I, } \\
\text { II \& III }\end{array}$ & Opening part & Opening part & Opening part & Point 7(c) \\
\hline
\end{tabular}


cheaters are conscious of their wrongdoing, whereas plagiarists may not necessarily understand that their actions are unacceptable (Jiang et al. 2013, p. 377). Thus, the word "jiplak" is ambiguous meanings and could be misleading as it does not represent the crucial need for accrediting the work of others. As a result, there is some confusion regarding the position of plagiarism amongst other forms of academic misconduct (Joy et al., 2013; Glendinning, 2014). As the ANES 2003 presented a general policy statement, other documents need to provide a more detailed definition of plagiarism. The RPMPHE 2010 endeavoured to narrow the broad notion of plagiarism definition offered by the ANES 2003. The RPMPHE 2010 presented the definition of plagiarism in chapter I, article 1, unit 1.The definition had explored the purpose of plagiarists when plagiarising, and in which behaviour can be classified as plagiarists.

"Plagiarism refers to intentional or unintentional acts to gain or to endeavour credits or marks from a scientific work by quoting others' work, either partially or completely, claimed as one's work without accrediting the source correctly and appropriately".

In the RPMHE 2010 policy document, the word "jiplak", or copying, was addressed with more specific lexical choice, such as "plagiarism", which is more commonly understood by academics. The RPMPHE 2010 definition further clarified plagiarism by classifying types of plagiarism as "intentional" and "unintentional" to help differentiate plagiarism and cheating. The purposes of plagiaristic acts, such as "endeavour credits" and "marks", help specify the conduct of plagiarism more clearly as compared the term "degree" in the ANES 2003 that suggests plagiarism is only relevant to theses and dissertations.

The RPMPHE 2010 provides an explanation of plagiarism with lexical usage involving actions: "quoting other work" and "without accrediting", product: "partially or completely" and manner: "correctly and appropriately". The definition of plagiarism reflected in the literature as "copy and pasting", "absence of acknowledgement" and "presenting as their own" (Orim et al., 2013). However, the plagiarism definition offered by the RPMPHE 2010 appears to be lacking in detail and consistency. For example, the boundaries between "intentional" and "unintentional" was not clearly defined. This was the "grey area" that can be problematic for academics to define, and many plagiarism policies the institutional level fail to define acceptable and unacceptable behaviour in terms of plagiarism (Joy et al., 2013, p. 16).

RPMPHE 2010 also added more explanations of types of plagiarism and behaviours of plagiarists in chapter I, article 1, unit 2. It stated that types of plagiarism included "Referring and/or quoting terms, words and/or sentences, data and/or information, ... ...... .quoting randomly terms, words and/or sentences, data and/or information, ....... using sources of ideas, opinions, views, or theories, ... from a source" without acknowledging the source. With repeated used of "without adequately expressing the source, RPMPHE 2010 endeavoured to instilled the academic culture of respecting the rights of other intellectual property to avoid plagiarism. The RPMPHE further elaborated types of academic works such as scientific papers, music compositiosn and computer software that were potentially plagiarised to prevent misunderstanding that plagiarism was limited to scientific publications and to protect other types of academic output. 
The three circular letters produced (from GDHE and DRCS) did not offer a definition of plagiarism. What was interesting regarding the intertextuality content of these documents was that the letters referred to the RPMPHE 2010 in the opening statements to draw attention to the RPMPHE 2010 as the core document for plagiarism discussion. The three circular letters referred the RPMPHE as the setting for communication.

"As we know, The Ministry of National Education has published Regulation of Ministry of National Education Number: 17 year 2010 ... .." GDHE circular letter on Prevention and Eradication.

"Following up the Regulation of The Ministry of National Education Number 17, 2010 regarding Prevention and Eradication of Plagiarism in Higher Education .." GDHE circular letter on Validation of Scientific Work.

"On behalf of implementation of Regulation of Minister of National Education No.

\section{7, 2010 on Prevention and Eradication of Plagiarism in Higher Education on 16}

August 2010," GDHE circular letter on Uploading Academic Work.

Reference to the RPMPHE 2010 with no further efforts to additionally define or clarify plagiarism in the circular letters suggests agreement with the content of the RPMPHE 2010. However, in circular letter of GDHE regarding prevention and eradication of plagiarism, the author of the document admitted that multiple interpretations of RPMPHE 2010 might occur among academics. We suggest that these interpretations could possibly include a misunderstanding of intentional and unintentional plagiarism and negatively impact the implementation of RPMPHE 2010, but the circular letter does not directly address this possibility

The definition proposed by the DGECRI of ITB includes additional elements to clarify plagiarism based on the definitions proposed by the RPMPHE 2010 and the ANES 2003. This policy document addresses the importance of acknowledging assistance of others in the research process, research ethics and recognising the work and ideas of others as intellectual property:

"Plagiarism includes acknowledging/claiming the work and ideas of others, using the results or methods of others without citing sources, deliberately do not declare a significant assistance received from the other parties, copy writing, and/or images or other types that are the works of others without stating the recognition of the authors, and recognises/claims the works and ideas of others or take their intellectual property"

The DGECRI of ITB policy document provides clarity in defining plagiarism that is helpful in raising awareness of acknowledging the work of others as intellectual property (Wheeler, 2014). The DGECRI of ITB policy was adapted from two international universities' research ethics processes and endeavoured to inculcate academic integrity values of international universities because of poor academic integrity exemplars in Indonesian universities. Thus, the DGECRI potentially has strong intertextuality with these documents 
as well as the local documents from a Ministerial level. This is perhaps because as a research-intensive institution, ITB has many staff who would have studied abroad and consequently, as highlighted by Gow (2014) could act as a cultural bridge in research ethics as these graduates contribute to improving research ethics guidelines and ideology regarding plagiarism and academic integrity. However, despite the definitions and refinements of the definitions of plagiarism, the difference between plagiarism by students and that by staff is not touched upon in the definitions in any of the documents, even the ITB with its western influences. Perhaps this is because staff studying abroad predominantly were research graduates focussing on the research aspect.

\section{Plagiarism prevention}

Communication dealing with plagiarism prevention within the plagiarism policy documents can be identified in the entire levels in the hierarchy. Table 3 illustrates the plagiarism prevention communication placed in the documents.

Policy documents were examined for the presence of efforts aimed at preventing plagiarism. The ANES 2003 revealed no specific efforts to prevent possible infringements of academic integrity amongst academics. There was little, if any, evidence of awareness amongst agents that established the ANES 2003 policy document that plagiarism may be prevalent amongst academics in different ways. A possible reason for this lack of awareness is that plagiarism was not regarded a serious academic breach in this context at the time and therefore, it was not considered as policy priority in the document as only a small proportion of the document included plagiarism policy. This lack of awareness of the importance of addressing plagiarism could have implications on perceiving plagiarism as a serious offence as plagiarism policy and practices in term of prevention may not be effectively be aligned. For example, academics may not communicate academic integrity and avoid plagiarism in their everyday teaching (Orim et al., 2013; Mahmud and Bretag 2013).

Efforts to prevent plagiarism amongst academics in the ANES 2003 were found in chapter V article 12 unit 2 and chapter XI article 40 unit 2. The use of lexical items such as "abiding by educational norms" for students and "be role model and uphold the reputation of their institution" for academics implied that efforts to avoid plagiarism and to maintain academic integrity at that time placed responsibility on university students and academics for maintaining ethical academic norms. The question about what institutions should put into practice to prevent plagiarism was not addressed in the ANES 2003 policy document.

Table 3 The contents of plagiarism prevention amongst plagiarism policy documents

\begin{tabular}{|c|c|c|c|c|c|c|}
\hline \multirow[t]{2}{*}{ Theme } & \multirow[t]{2}{*}{ ANES 2003} & \multirow{2}{*}{$\begin{array}{l}\text { RPMPHE } \\
2010\end{array}$} & \multicolumn{3}{|l|}{ Circular Letters } & \multirow{2}{*}{$\begin{array}{l}\text { Guidance } \\
\text { of Ethics } \\
\text { for } \\
\text { Research } \\
\text { Integrity }\end{array}$} \\
\hline & & & $\begin{array}{l}\text { GDHE: Plagiarism } \\
\text { prevention and } \\
\text { Mitigation }\end{array}$ & $\begin{array}{l}\text { GDHE: Scientific } \\
\text { Work Validation }\end{array}$ & $\begin{array}{l}\text { DRCS: } \\
\text { Uploading } \\
\text { academic work }\end{array}$ & \\
\hline $\begin{array}{l}\text { Prevention } \\
\text { of } \\
\text { plagiarism }\end{array}$ & $\begin{array}{l}\text { Chapter V } \\
\text { Article } 12 \\
\text { Unit 2 } \\
\text { Chapter XI } \\
\text { Article } 40 \\
\text { Unit 2 }\end{array}$ & $\begin{array}{l}\text { CHAPTER } \\
\text { IV } \\
\text { Article 6, } \\
78 \& 9\end{array}$ & Letter content & Letter content & Letter content & $\begin{array}{l}\text { Point 1, } 2, \\
3 \& 4\end{array}$ \\
\hline
\end{tabular}


In response to the need to devise a more holistic plagiarism prevention strategy, RPMPH 2010, on the other hand, provided a specific chapter regarding practices for plagiarism prevention in HE. The chapter consists of four articles that promote preventive measures involving university leaders and HE institutions to take action to foster sound academic integrity. The preventive measures are specifically: provision and supervision of ethics codes, monitoring of academic genre implementation, declaration of not plagiarising by all academics for academic work, uploading academic works to a special database called the Garuda Portal and peer review for professional promotion and professorship. These measures emphasise a shared responsibility amongst different academics with intention to inculcate anti-plagiarism culture at the meso-level of department and faculty, which is the domain where academic cultural reform is best targeted (Baughan 2013).

The establishment of the RPMPHE 2010 plagiarism policy implies that the policy response was triggered by the serious plagiarism case noted above. It was noted that between the ANES 2003 and the RPMPHE 2010 is a long time for policy revision and plagiarism prevention efforts. In addition, the RPMPHE 2010 policy document was designed to focus on the personnel of Indonesian HE institutions. It suggested that certain agents brought plagiarism prevention as an urgent issue to public and government attention to promote a more robust approach to combating plagiarism. The urgency for provision of plagiarism prevention regulation resulted in a more specific and holistic plagiarism prevention policy. However, the RPMPHE 2010 tended to overlook technology interventions, such as the use of plagiarism prevention software to minimise plagiarism through detection. It may be because the technology were only substantially researched after the introduction of the policy (e.g. Moore 2014; Vieyra et al. 2013; Sousa-Silva 2014; Meuschke and Gipp 2013; Coughlin 2015; Larsson and Hansson 2013), whereas, plagiaristic techniques had already become more complex (e.g. Vieyra et al. 2013). Thus, a more sophisticated approach such as utilisation of plagiarism detection software was required to address these challenges.

Analysis of the two circular letters of GDHE and one from DRCS supported the notion that intensive efforts for plagiarism prevention took place during 2010. The three circular letters dated 18 October 2010, 16 February 2011 and 8 July 2011 indicated intensive efforts to minimise plagiarism amongst HE practitioners. The three circular letters addressed the urgency for validation of academic work for professorship proposals, misinterpretation amongst academics about peer review for professional promotion and professorship, and uploading academic work through a special database, namely Garuda Portal. It appears that the three circular letters were established to assist the RPMPHE 2010 to effectively and intensively communicate plagiarism prevention efforts.

At the institutional level, the DGECRI of ITB encouraged the inculcation of academic integrity values as an important element of plagiarism prevention efforts. The phrase "an honest, sincere, responsible and hold unwavering commitment to fulfil the promise" indicates that the institution required academics to uphold the moral values of academic integrity by expecting moral reflection, both individually characters and as an institution. The phrase "not only maintain integrity on behalf of himself, but also to build the positive image and figure of ITB" indicates that the DGECRI regarded ITB academics as inseparable from the university's reputation. In addition, the DGECRI 
repeatedly uses the term "all parties" with intention of eliminating discrimination between students, academics and stakeholders. For example, "All parties maintain quality processes and methodologies in the implementation of research" suggesting that the objective is shared responsibility amongst academics to foster academic integrity. Yet as noted above, there is limited 'transformation' in the DGECRI to identify ways to practically support students in avoiding plagiarism.

\section{Punishment for plagiarists}

The communication about punishment for plagiarism in Indonesian higher education contexts, as described in the collected plagiarism policy documents appears that only top policy makers with powerful authorities in the hierarchy could speak about punishment. Table 4 locates communication of punishment for plagiarism among the plagiarism policy documents.

Analysis of plagiarism policy documents revealed that the "right" and "power" to punish breaches of academic integrity were found at the macro level of document policy hierarchy. As the highest document in the hierarchy, the ANES 2003 articulates punishment for plagiarists in chapter VI article 25 and chapter XX article 70:

"An academic, professional, or technical and vocational degree awarded shall be revoked, if his/her thesis/dissertation is a plagiarism".

"A graduate whose academic work for obtaining degree set forth in article 25 verse (2) is found to be plagiarism, shall be liable to imprisonment of up to two years and/or to maximum fine of Rp. 200.000.000,00 (two hundred million rupiahs)."

Sanctions for plagiarists in the ANES 2003 include "cancellation of a degree" and "imprisonment" and/or "fine" implying that plagiarism is perceived in this policy document as a severe academic breach. This policy document did not seek any other possibility of plagiarism such as plagiarising for professional promotion. Additionally, the document did not provide direction regarding punishment for intentional and unintentional plagiarism. The purpose of plagiaristic acts were narrowed to obtaining academic degrees. The punishment tended to target graduate rather than students, which is similar to flaws in defining plagiarism in article 25 unit 2. In addition, the policy document punished plagiarists with up to 2 years imprisonment and a significant fine to promote deterrence of academic integrity infringement. This indicates that plagiarism at this time was perceived as a criminal act.

Analysis of plagiarism sanctions in the RPMHE 2010 policy document revealed a shift of perception between the ANES 2003 and the RPMPHE 2010 regarding appropriate

Table 4 The contents of defining plagiarism amongst plagiarism policy documents

\begin{tabular}{|c|c|c|c|c|c|c|}
\hline \multirow[t]{2}{*}{ Theme } & \multirow{2}{*}{$\begin{array}{l}\text { ANES } \\
2003\end{array}$} & \multirow{2}{*}{$\begin{array}{l}\text { RPMPHE } \\
2010\end{array}$} & \multicolumn{3}{|l|}{ Circular Letters } & \multirow{2}{*}{$\begin{array}{l}\text { Guidance of } \\
\text { Ethics for Research } \\
\text { Integrity }\end{array}$} \\
\hline & & & $\begin{array}{l}\text { GDHE: Plagiarism } \\
\text { prevention and } \\
\text { Mitigation }\end{array}$ & $\begin{array}{l}\text { GDHE: Scientific } \\
\text { Work Validation }\end{array}$ & $\begin{array}{l}\text { DRCS: Uploading } \\
\text { academic work }\end{array}$ & \\
\hline $\begin{array}{l}\text { Punishment } \\
\text { for plagiarists }\end{array}$ & $\begin{array}{l}\text { Chapter } \\
\text { XX Article } \\
70\end{array}$ & $\begin{array}{l}\text { Chapter } \\
\text { VI }\end{array}$ & - & - & - & - \\
\hline
\end{tabular}


sanctions for plagiarists. The ANES 2003 perception of plagiarism as a crime was revised in the RPMPHE 2010 with other potential forms of punishment for plagiarists. The RPMPHE 2010 successfully negotiated a different approach to punishment for academic infringement by accommodating the need for clarity of sanctions between students, academics and policy makers. In terms of student sanctions, options provided were from subtle to more severe punishment for plagiarism adjudication. These options were given to reduce confusion amongst faculty about sanctions for different types and levels of university student plagiarism. Likewise, sanctions for academics who plagiarised ranged from subtle punishment to more severe punishment. However, punishment for academics was different to student sanctions as academics could be punished by both academic and professional suspension. The RPMPHE 2010 further gave sanctions for professors and candidate professors. To involve all academia including the leaders of universities to combat plagiarism, this document included sanctions for policy makers and university leaders who were not cooperative in the process of prevention and mitigation of plagiarism. The punishment for students, faculty and policy makers is presented (Table 5).

The RPMPHE 2010 promoted a holistic approach to sanctions for plagiarists. It included the agents in HE that may potentially be involved in plagiaristic acts suggesting that all elements in the HE institution need to maintain academic integrity regardless of their position as students, academics or professors. The plagiarism policy also endeavoured to overcome potential obstacles of prevention and mitigation efforts, such as university leader's passive participation, but did not provide details on how to actively participate beyond severe sanctions for intentional plagiarism. Educative approaches to plagiarism for students are not touched upon.

The sanctions for plagiarism directed to university leaders show that the RPMPHE 2010 expected proactive action from leadership in response to incidences of plagiarism. However, the notion of unintentional and intentional/repeated plagiarism were unclarified and ambiguous in this document. This implies that the line between intentional and unintentional plagiarism are for $\mathrm{HE}$ practitioners to interpret.

Table 5 Punishment of plagiarism amongst university students, faculty, professors and university leaders imposed in RPMPHE 2010

\begin{tabular}{|c|c|c|c|c|c|c|c|}
\hline \multirow{10}{*}{ 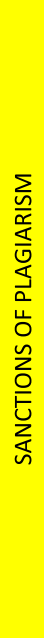 } & \multirow{5}{*}{ 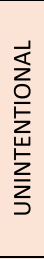 } & $\begin{array}{l}\text { UNIVERSITY } \\
\text { STUDENTS }\end{array}$ & FACULTY & PROFESSORS & \multirow{10}{*}{ 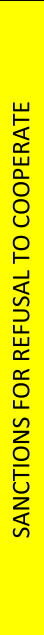 } & $\begin{array}{l}\text { UNIVERSITY } \\
\text { LEADERS }\end{array}$ & \multirow{10}{*}{ 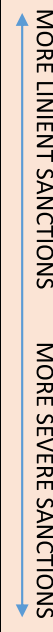 } \\
\hline & & Oral Warning & Oral Warning & Oral Warning & & Oral Warning & \\
\hline & & Written warning & $\begin{array}{l}\text { Written } \\
\text { warning }\end{array}$ & $\begin{array}{l}\text { Written } \\
\text { warning }\end{array}$ & & & \\
\hline & & $\begin{array}{l}\text { Students' right } \\
\text { cancellation }\end{array}$ & $\begin{array}{l}\text { Faculty's right } \\
\text { cancellation }\end{array}$ & $\begin{array}{l}\text { Faculty's right } \\
\text { cancellation }\end{array}$ & & & \\
\hline & & & Demotion & Demotion & & & \\
\hline & 옳 & $\begin{array}{l}\text { Cancellation of } \\
\text { scores }\end{array}$ & $\begin{array}{l}\text { Revocation for } \\
\text { professor } \\
\text { promotion } \\
\text { right }\end{array}$ & $\begin{array}{l}\text { Revocation for } \\
\text { professor } \\
\text { promotion } \\
\text { right }\end{array}$ & & & \\
\hline & 品 & Discharge & $\begin{array}{l}\text { Discharge } \\
\text { honourably }\end{array}$ & $\begin{array}{l}\text { Discharge } \\
\text { honourably }\end{array}$ & & & \\
\hline & $\frac{1}{z}$ & $\begin{array}{l}\text { Dishonourable } \\
\text { discharge }\end{array}$ & $\begin{array}{l}\text { Dishonourable } \\
\text { discharge }\end{array}$ & $\begin{array}{l}\text { Dishonourable } \\
\text { discharge }\end{array}$ & & $\begin{array}{l}\text { Revocation of } \\
\text { Judicial }\end{array}$ & \\
\hline & 证 & $\begin{array}{l}\text { Certificate } \\
\text { cancellation }\end{array}$ & $\begin{array}{l}\text { Certificate } \\
\text { cancellation }\end{array}$ & $\begin{array}{l}\text { Certificate } \\
\text { cancellation }\end{array}$ & & & \\
\hline & $\underline{z}$ & & & $\begin{array}{l}\text { Dismissal of } \\
\text { professorship }\end{array}$ & & & \\
\hline
\end{tabular}


Policy makers should address the need for clarification of intentional and unintentional plagiarism because this was a domain of disagreement amongst faculty identified in the literature. Despite the recommendations in the RMPHE for universities to take a leading role, this has not been done in the DGECRI, signalling that the punishment of plagiarism would remain the domain of the higher levels of the hierarchy. This is despite the fact that the ITB academics studying abroad would have been potentially been exposed to more 'educative' approaches for undergraduates and coursework students.

\section{Conclusion}

In conclusion, this study has endeavoured to provide a picture of plagiarism prevention and mitigation policy in the context of Indonesian Higher Education through a hierarchical structure that revealed the important policy-makers in Indonesian Higher education. There are several lessons learned from the in-depth analysis of the plagiarism discourses revealed in policy and possible further ways to support academic integrity practice. Plagiarism mitigation tends to focus on faculty by imposing more prevention and punishments for acts by faculty although mention is also made of severe punishments for student plagiarists in the RMPHE. However, the onus seems to remain at the Ministerial level to punish the student plagiarists. The emphasis on plagiarism policy for faculty may offer tangible intended results because role modelling is crucial in this context, and therefore may reduce plagiarism incidences among students. However, it is also equally important for policy makers to ensure that plagiarism policy equally address plagiarism among students and faculty with no discrimination and to provide practical implementation suggestions in order to educate students against plagiarism, provide levels of sanctions appropriate to the breach and support for academic integrity. Furthermore, it appears that plagiarism policy developers in Indonesian Higher Education (the President of the Republic of Indonesia, the Ministry of National Education, the General Directorate, the Director of Directorate of Research and the rector) have collectively been negotiating the definition of plagiarism because plagiarism was initially a newly used academic term in this context. Therefore, there is a need for defining plagiarism among Indonesian higher education institutions in a contextually relevant way. However, perhaps because of the strong hierarchical structure of Indonesian HE, and the strong "manifest intertextuality" (Fairclough, 1992: 286) enforced by adherence to this hierarchy, the institutional policy studies appears to lack detail on how to practically support plagiarism prevention and sanctions in an appropriate way for students. Perhaps, more detail on the implementation of policy in practice from a Ministerial level would support such elaboration or perhaps a stronger emphasis on internationally trained academics drawing on teaching as well as research practice would result in more transference of practice from international contexts. In particular, in order to effectively implement academic integrity at a university level, Indonesian Higher Education policy makers and implementers are further required to interpret the degree of plagiarism (e.g. Patrzek, Sattler, van Veen, Grunschel, \& Fries, 2015; Joy et al., 2013) especially in the domains of unintentional and intentional plagiarism and then allocate penalties ranging from lenient to severe according to the criteria (see Table 5). The degree needs fitting with the prevention 
and more importantly punishment as suggested in the policy documents. This is a future potential of research to explore. In addition, the perspectives of policy makers and implementers on the reasons why they have engaged interdiscursively in specific ways and why they have failed to transform higher level policies for their local contexts remains an area for further research.

\title{
Translation of terminology
}

\section{Act: undang-undang}

2. Circular (letter): surat edaran

\section{Government Regulation: Peraturan Pemerintah}

\begin{abstract}
Abbreviations
ANES 2003: The Act of the Republic of Indonesia Number 20 Year 2003 on the National Education System; DGECRI of ITB: The Decree of Rector of Bandung Institute of technology on Guideline of Ethic Codes for Research Integrity; DRCS: Director of Research and Community Service; GDHE: General Director of Higher Education; HE: Higher Education; MNERI: The Minister of National Education of the Republic of Indonesia; PRI: The President of the Republic of Indonesia; RPMPHE 2010: The Regulation of the Ministry of National Education of the Republic of Indonesia Number 17 Year 2010 on Prevention and Mitigation of Plagiarism in Higher Education
\end{abstract}

\section{Acknowledgements}

Dr. Dana Thomsen who formerly worked at the University of Adelaide provided proofreading services for the dissertation from which this article was developed at the end of 2015. I acknowledge the Australian Government support through the Australia Award Scholarship scheme.

\section{Authors' contributions}

A wrote the introduction, wrote the methodology, collected and analysed, results and wrote the first draft of the article. MP supported the overall research design and methodology, and structure and style of the article especially word choices and sentence choice to clarify meanings. Both authors read and approved the final manuscript.

\section{Authors' information}

Akbar is a lecturer of State Islamic Institute of Palopo, Indonesia. His research interest includes higher education, academic integrity and English Learning and Teaching in Higher Education. He is currently a first year student of PhD (Education) studying at the University of Newcastle.

Michelle Picard is Akbar's PhD supervisor at the University of Newcastle and was formally his Masters Dissertation supervisor at the University of Adelaide. She is now Dean of Teaching and Learning in the College of Arts, Business, Law and Social Sciences at Murdoch University in WA, Australia. Here research interests are academic literacies, especially academic integrity.

\section{Funding}

This article is part of Dissertation for the first Author's Master Degree Completion at the University of Adelaide funded by the Australia Award Scholarship 2013.

\section{Availability of data and materials}

The data for this study can be downloaded from the following link:

1. The Act of the Republic of Indonesia Number 20 Year 2003 on National Education System, can be downloaded from: https://kelembagaan.ristekdikti.go.id/wp-content/uploads/2016/08/UU_no_20_th_2003.pdf

2. The Regulation of the Minister of National Education of the Republic of Indonesia Number 17 Year 2010 on Prevention and Eradication of Plagiarism in Higher Education can be downloaded from: https://idr.uin-antasari.ac.id/4 79/1/Permendiknas-no.-17-tahun-2010-tentang-Pencegahan-Plagiat.pdf

3. Circular Letter of the General Director of Higher Education on Prevention and Eradication of Plagiarism Number 1311/D/C/2010 can be downloaded from the following link: http://luk.staff.ugm.ac.id/atur/SEDirjen1311-D-C-201 OPlagiat.pdf

4. Circular Letter of the General Director of Higher Education on Validation of Scientific Work can be downloaded here: https://luk.staff.ugm.ac.id/atur/SEDirjen190-D-T-2011ValidasiKaryallmiah.pdf

5. Circular Letter of the General Director of Higher Education on Validation of Scientific Work Number 1444/E54/LL/ 2011 can be downloaded here: http://ldikti12.ristekdikti.go.id/2011/07/31/himbauan-publikasi-jurnal-atau-terbitanberkala-ilmiah-di-portal-garuda-ditjen-dikti.html

6. The Decree of Rector of Bandung Institute of Technology on Guideline of Ethic Codes for Research Integrity can be downloaded through this link: https://multisite.itb.ac.id/sith/wp-content/uploads/sites/56/2017/02/2011_SKRektor_24_ PanduanKodeEtikIntegritasRisetITB.pdf

\section{Competing interests}

The authors declare that they have no competing interests. 
Author details

${ }^{1}$ Institut Agama Islam Negeri Palopo, Palopo, Sulawesi Selatan, Indonesia. ${ }^{2}$ The University of Newcastle Newcastle, Australia. ${ }^{3}$ Murdoch University, Perth, Australia.

Received: 24 July 2019 Accepted: 30 September 2019

Published online: 30 October 2019

\section{References}

Adiningrum TS (2015) Reviewing plagiarism: an input for Indonesian higher education. J Acad Ethics 13(1):107-120

Adiningrum TS, Wihardini D, Warganegara DL (2013) Awareness or understanding? A case study of assessing Indonesian academic staff understanding of plagiarism. Educ Soc 31(1):69-81

Baughan P (2013) The missing meso: variation in staff experiences of an academic practice initiative and lessons for educational change. Int J Educ Integr 9(1):89-100

Coughlin PE (2015) Plagiarism in five universities in Mozambique: Magnitude, detection techniques, and control measures. Int J Educ Integr 11(1):1-19

Ditjen Dikti. (2011a) The publication of scientific works. http://www.kopertis12.or.id/2011/07/31/himbauanpublikasi-jurnalatau-terbitan-berkala-ilmiah-di-portal-garuda-ditjen-dikti.html. Accessed 24 Sept 2015

Ditjen Dikti. (201 1b) Validating Scientific works. http://www.kopertis12.or.id/2011/03/03/se-dirjen-dikti-ttg-validasi-karya-ilmiahbagi-pengusulan-jafung-lektor-kepala-dan-guru-besar.html. Accessed 24 Sept 2015

Fairclough N (1992) Intertextuality in critical discourse analysis. Linguist Educ 4:269-293. https://doi.org/10.1016/08985898(92)90004-G

Glendinning I (2014) Responses to student plagiarism in higher education across Europe. Int J Educ Integr 10(1):4-20

Gow S (2014) A cultural bridge for academic integrity? Mainland Chinese master's graduates of UK institutions returning to China. Int J Educ Integr 10(1):70-83

Jiang $H$, Emmerton L, McKauge $L$ (2013) Academic integrity and plagiarism: a review of the influences and risk situations for health students. High Educ Res Dev 32(3):369-380

Joy M, Sinclair J, Boyatt R, Yau JK, Cosma G (2013) Student perspectives on source-code plagiarism. Int J Educ Integr 9(1):3-19 Kamus Besar Bahasa Indonesia. (n.d.). Jiplak https://kbbi.web.id/jiplak. Accessed 09 Sept 2019

Larsson K, Hansson H (2013) Anti-plagiarism strategies: how to manage it with quality in large-scale thesis productions. Int J Educ Integr 9(2):60-73

Mahmud S, Bretag T (2013) Postgraduate research students and academic integrity: 'It's about good research training'. J High Educ Policy Manag 35(4):432-443

Menteri Pendidikan Nasional (2010) The Regulation of the Minister of National Education of the Republic of Indonesia Number 17 Year 2010 on Prevention and Eradication of Plagiarism in Higher Education (RPMPHE 2010). https://idr.uinantasari.ac.id/479/1/Permendiknas-no.-17-tahun-2010-tentang-Pencegahan-Plagiat.pdf. Accessed 7 August 2019.

Meuschke N, Gipp B (2013) State-of-the-art in detecting academic plagiarism. Int J Educ Integr 9(1):50-71

Moore E (2014) Accuracy of referencing and patterns of plagiarism in electronically published theses. Int J Educ Integr 10(1): $42-55$

Orim SMI, Davies JW, Borg E, Glendinning I (2013) Exploring Nigerian postgraduate students' experience of plagiarism: a phenomenographic case study. Int J Educ Integr 9(1):20-34

Patrzek J, Sattler S, van Veen F, Grunschel C, Fries S (2015) Investigating the effect of academic procrastination on the frequency and variety of academic misconduct: a panel study. Stud High Educ 40(6):1014-1029

Presiden Republik Indonesia (2003). The Act of the Republic of Indonesia Number 20 Year 2003 on National Education System (ANES 2003).https://kelembagaan.ristekdikti.go.id/wp-content/uploads/2016/08/UU_no_20_th_2003.pdf. Accessed 16 Mar 2019

Presiden Republik Indonesia. (2011). The Constitutions of the Republic of Indonesia Number 12 year 2011 regarding enactment of constitution regulation. https://www.google.com.au/search?q=undang+undang+nomor+12+tahun+2011 $\& i e=u t f-8 \& o e=u t f-8 \& g w s$ rd $=$ cr\&ei=RoINVr3ZPInF0gSzmISYAQ. Accessed 28 Aug 2015

Presiden Republik Indonesia. (2015). The regulation of the President of the Republic of Indonesia number 14 Year 2015 regarding the Ministry of Education and Culture. https:/www.google.com.au/url?sa=t\&rct=j\&q=\&esrc=s\&source= web\&cd=5\&ved=0CEIQFjAEahUKEwjerfX|6vz|AhWBkKYKHUj8Bag\&url=https\%3A\%2F\%2Fwww.kemenkopmk.go.id\%2 Fsites\%2Fdefault\%2Ffiles\%2Fprodukhukum\%2FPerpres\%2520Nomor\%252014\%2520Tahun\%25202015.pdf\&usg= AFQjCNHNEiSW9uhQDAluxQo9syxUpRBIlw. Accessed 28 Aug 2015

Siaputra IB (2013) The 4PA of plagiarism: a psycho-academic profile of plagiarists. Int J Educ Integr 9(2):50-59

Siaputra IB, Santosa DA (2015) Academic integrity campaign in Indonesia. In: Bretag T (ed) Handbook of academic integrity. Springer Reference, Singapore

Sousa-Silva R (2014) Investigating academic plagiarism: a forensic linguistics approach to plagiarism detection. Int J Educ Integr 10(1):31-41

The Jakarta Post. (2010). Graduate Deplored by lecturer for plagiarism https://www.thejakartapost.com/news/2010/04/20/ graduate-deplored-lecturer-plagiarism.html. Accessed 02 Sept 2019

Vieyra M, Strickland D, Timmerman B (2013) Patterns in plagiarism and patch writing in science and engineering graduate students' research proposals. Int J Educ Integr 9(1):35-49

Wheeler G (2014) Culture of minimal influence: A study of Japanese university students' attitudes toward plagiarism. Int $J$ Educ Integr 10(2): 44-59.

Wibowo A (2012) Mencegah dan menanggulangi plagiarisme di dunia pendidikan. Jurnal Kesehatan Masyarakat Nasional 6(5):198-200

\section{Publisher's Note}

Springer Nature remains neutral with regard to jurisdictional claims in published maps and institutional affiliations. 